\title{
Phytoprotection
}

\section{Histopathology of Fusarium wilt of staghorn sumac (Rhus typhina) caused by Fusarium oxysporum f. sp. callistephi race 3. I. Modes of tissue colonization and pathogen peculiarities L'histopathologie de la fusariose du vinaigrier (Rhus typhina) causée par le Fusarium oxysporum f. sp. callistephi race 3. I. Modes de colonisation de l'hôte et particularités de l'agent pathogène}

\author{
Guillemond B. Ouellette, Mohamed Cherif, Marie Simard et Louis Bernier
}

Volume 86, numéro 3, décembre 2005

URI : https://id.erudit.org/iderudit/013074ar

DOI : https://doi.org/10.7202/013074ar

\section{Aller au sommaire du numéro}

\section{Éditeur(s)}

Société de protection des plantes du Québec (SPPQ)

ISSN

0031-9511 (imprimé)

1710-1603 (numérique)

Découvrir la revue

Citer cet article

Ouellette, G. B., Cherif, M., Simard, M. \& Bernier, L. (2005). Histopathology of Fusarium wilt of staghorn sumac (Rhus typhina) caused by Fusarium oxysporum f. sp. callistephi race 3. I. Modes of tissue colonization and pathogen peculiarities. Phytoprotection, 86(3), 157-174. https://doi.org/10.7202/013074ar

\section{Résumé de l'article}

Nous rapportons des observations microscopiques et ultrastructurales de l'infection par le $F$. oxysporum f. sp. callistephi race 3 de plants de vinaigrier inoculés ou infectés naturellement. Des structures ou du matériel étrangers aux éléments vasculaires ont été illustrés. Ce matériel ainsi que la matière liée à l'altération de la couche dite protectrice des cellules de parenchyme se sont marqués pour la pectine. Des corps opaques apposés aux parois des vaisseaux, présents dans leur lumière ou dans les cellules de parenchyme voisines, ont réagi pour la cellulose. La partie mitoyenne des membranes de ponctuation aréolées était altérée en lambeaux non marqués pour la cellulose et leur partie externe en corps opaques marqués. La pénétration des parois secondaires des cellules hôtes par le champignon a eu lieu, mais ces parois étaient fortement altérées seulement une fois colonisées de façon intralamellaire. Les parois vasculaires, à tous les stades de la maladie, étaient recouvertes de matière étrangère : dans les cas les plus prononcés, de couches de diverses épaisseurs, formées de strates d'opacité différente, et, dans leur plus simple expression, de lamelles opaques, simples ou jumelées mais souvent divergentes; des éléments, encadrés de lamelles semblables et souvent incurvées, et contenant de la matière opaque, des structures vésiculaires ou occasionnellement des particules semblables à des ribosomes garnissaient également les parois vasculaires. Ces éléments, inégalement marqués pour la chitine, étaient à l'occasion liés à des cellules du champignon. La couche translucide de ces cellules était souvent mince ou absente, pratiquement non marquée pour ce substrat, ou localement épaissie et alors fortement marquée, comme aussi occasionnellement leur couche pariétale externe et la matière extracellulaire semblable. Des structures filamenteuses rattachées aux cellules du champignon, comme au recouvrement des parois vasculaires et aux autres éléments, piquaient les parois cellulaires de l'hôte. Ces recouvrements ne se sont généralement pas marqués pour la cellulose ou la chitine. Ces observations se comparent avantageusement à celles concernant les autres maladies à flétrissement que nous avons étudiées.
Tous droits réservés @ La société de protection des plantes du Québec, 2005
Ce document est protégé par la loi sur le droit d'auteur. L'utilisation des services d’Érudit (y compris la reproduction) est assujettie à sa politique d'utilisation que vous pouvez consulter en ligne.

https://apropos.erudit.org/fr/usagers/politique-dutilisation/ 


\title{
Histopathology of Fusarium wilt of staghorn sumac (Rhus typhina) caused by Fusarium oxysporum f. sp. callistephi race 3. I. Modes of tissue colonization and pathogen peculiarities
}

\author{
Guillemond B. Ouellette', Mohamed Cherif², Marie Simard'1, and Louis Bernier ${ }^{3}$
}

Received 2005-05-23; accepted 2006-02-20

PHYTOPROTECTION 86 : 157-174

Light and transmission electron microscope studies of naturally infected or inoculated staghorn sumac plants by Fusarium oxysporum f. sp. callistephi race 3 are reported. Diverse extrinsic material (including latex in some instances) or elements occurred in vessel lumina. Some of this material labelled for pectin, often in association with tyloses, as did other opaque matter in paratracheal cells, related to alterations of their protective layer. Pronounced alterations of pit membranes of bordered pits occurred, with their outer portions disrupted into bodies of opaque matter, strongly labelled for cellulose, and their middle portions as unlabelled shreds. Similarly labelled opaque bodies occasionally occurred on vessel walls and lumina. Direct penetration of host cell secondary walls by the pathogen occurred, but these were degraded to any extent only following intramural invasion. Vessel walls, at all stages of infection, were lined with variously structured matter: in their thinnest forms, by single or paired, equidistant or widely spaced opaque bands, and in their thickest forms as alternating opaque and less opaque layers. Other thin elements, often enclosing opaque material, vesicular structures, or occasionally particles of ribosomal appearance were also delineated by similar but frequently infolded bands. These elements were sometimes observed to be confluent with fungal cells and to label for chitin. Many fungal elements were bound by only a thin or defective lucent wall layer, practically unlabelled for chitin, or by a locally thickened, labelled one; labelling for this substrate was also frequently associated with the fungal cell outer opaque wall layer or with some outer extracellular matter. Fine filamentous structures, connected to fungal cells, to the vessel lining matter, and to these other elements, extended into host walls. The lining itself generally did not label for cellulose or chitin. These observations are discussed in comparison with similar observations made regarding other wilt diseases that we have studied.

Keywords: Cellulose, chitin, colloidal gold labelling, endocells, fungal wall irregularities, Fusarium wilt, pit membrane alterations, vessel wall linings.

[L'histopathologie de la fusariose du vinaigrier (Rhus typhina) causée par le Fusarium oxysporum f. sp. callistephi race 3. I. Modes de colonisation de l'hôte et particularités de l'agent pathogène]

Nous rapportons des observations microscopiques et ultrastructurales de l'infection par le F. oxysporum f. sp. callistephi race 3 de plants de vinaigrier inoculés ou infectés naturellement. Des structures ou du matériel étrangers aux éléments vasculaires ont été illustrés. Ce matériel ainsi que la matière liée à l'altération de la couche dite protectrice des cellules de parenchyme se sont marqués pour la pectine. Des corps opaques apposés aux parois des vaisseaux, présents dans leur lumière ou dans les cellules de parenchyme voisines, ont réagi pour la cellulose. La partie mitoyenne des membranes de ponctuation aréolées était altérée en lambeaux non marqués pour la cellulose et leur partie externe en corps opaques marqués. La pénétration des parois secondaires des cellules hôtes par le champignon a eu lieu, mais ces parois étaient fortement altérées seulement une fois colonisées de façon intralamellaire. Les parois vasculaires, à tous les stades de la maladie, étaient recouvertes de matière étrangère : dans les cas les plus prononcés, de couches de diverses épaisseurs, formées de strates d'opacité différente, et, dans leur plus simple expression, de lamelles opaques, simples ou jumelées mais souvent divergentes; des éléments, encadrés de lamelles semblables et souvent incurvées, et contenant de la matière opaque, des structures vésiculaires ou occasionnellement des particules semblables à des ribosomes

\footnotetext{
1. Natural Resources Canada, Canadian Forest Service, Laurentian Forestry Centre, 1055 du PEPS, P.O. Box 10380, Succ. Sainte-Foy, Québec (Québec), Canada G1V 4C7; corresponding author e-mail: gouellette@cfl.forestry.ca

2. Institut National Agronomique de Tunisie, 43 Charles Nicolle, 1082 Tunis-Mahrajène, Tunisie

3. Centre de recherche en biologie forestière, Pavillon C.-E. Marchand, Université Laval, Québec (Québec), Canada G1K 7P4
} 
garnissaient également les parois vasculaires. Ces éléments, inégalement marqués pour la chitine, étaient à l'occasion liés à des cellules du champignon. La couche translucide de ces cellules était souvent mince ou absente, pratiquement non marquée pour ce substrat, ou localement épaissie et alors fortement marquée, comme aussi occasionnellement leur couche pariétale externe et la matière extracellulaire semblable. Des structures filamenteuses rattachées aux cellules du champignon, comme au recouvrement des parois vasculaires et aux autres éléments, piquaient les parois cellulaires de l'hôte. Ces recouvrements ne se sont généralement pas marqués pour la cellulose ou la chitine. Ces observations se comparent avantageusement à celles concernant les autres maladies à flétrissement que nous avons étudiées.

Mots clés : Anomalies de la paroi fongique, bris des parois de ponctuation, cellules endocellulaires, cellulose, chitine, fusariose, marquage à l'or colloïdal, recouvrements des parois vasculaires.

\section{INTRODUCTION}

Staghorn sumac (Rhus typhina L.) is a shrub of wide occurrence in dry and rocky soils (Fernald 1950) along roadsides, exposed cliffs, or in borders of wooded areas. It is often planted as an ornamental, not only in America but also in Europe, and its velvety fruits have been used in popular medicine or as an ingredient in lemonade preparations (Kirouac 1995).

In 1993, numerous staghorn sumac plants that showed typical wilt disease symptoms, including xylem discoloration, were observed at several locations in the Quebec City region (Québec, Canada). Incubation of chips from surface-sterilized stems and petioles on potato dextrose agar (PDA) consistently yielded pure cultures of a fungus that was identified as Fusarium oxysporum f. sp. callistephi race 3 Armstrong \& Armstrong (Armstrong and Armstrong 1981), originally described as F. oxysporum f. sp. rhois (Snyder et al. 1949). The disease was prevalent in several locations the following years, and other isolates of the fungus, mostly of the whitish form (greyish and pinkish forms were also isolated from a locality in Wisconsin, by David Houston, Hamden, CT, USA, personal communication) were obtained from another location in the Québec region. The latex abundantly produced in the bark of diseased trees was either white (as in healthy plants), yellowish or purple. The yellowish latex occurred in apparently less severely affected plant parts and the purple latex in the more severely affected ones.

Fusarium wilt of sumac was first noted in midwestern states, USA (Toole et al. 1948), and reported in other states shortly thereafter, including northeastern states (Hepting and Toole 1950; Thomas 1950). Following various inoculation tests with Fusarium spp. obtained from different tree hosts, the isolates from staghorn sumac were found to be host specific (Snyder et al. 1949). Subsequently, the disease has not attracted much attention, and its presence in Québec might have been previously overlooked, and possibly confounded with other disorders (Farr et al. 1989; Kirouac 1995). Staghorn sumac wilt has also been recorded in Slovakia, caused either by Fusarium or Verticillium sp. (Prof. Gabriela Juhásová, Ústav ekologie lesa, SAV, Zvolen, Slovakia, personal communication).

Apart from observations that vessel elements in the host plants inoculated with the pathogen were easily colonized (Toole 1949), no further histopathological investigations of the disease have been reported. We were prompted to further investigate the mode of infection by this fungus in staghorn sumac, primarily to verify if the main infection processes were comparable to those observed in elms infected by the Dutch elm disease (DED) pathogen (Ophiostoma novo-ulmi Brasier) (Ouellette and Rioux 1992, 1993; Ouellette et al. 1995) and in carnation affected with Fusarium wilt (Ouellette et al. 1999a). Prominent features in carnation were alterations ascribed to small elements, labelling for chitin, and that were only delimited by fine, often convoluted bands (Ouellette et al. 2004a), and to bands or masses of opaque matter containing opaque particles grouped into paracrystalloids (Ouellette et al. 2004b).

The objectives of this work were to provide an overview of the infection process of the disease, with particular emphasis on the mode of tissue invasion, on the material accumulating in lumina of vessel elements and on their walls, and on fungal cell morphology. Many observations were obtained from tests with gold-complexed probes to detect pectin, cellulose, and chitin.

\section{MATERIAL AND METHODS}

\section{Naturally infected material}

Staghorn sumac plants showing various wilt symptom intensities, collected in the Quebec City area, were cut in early September 1993, late August 1995, or late September 2000, and brought immediately to the laboratory for fixation. Only the plants from which the Fusarium pathogen was isolated in pure cultures on $2 \%$ PDA were used as study material. Four or five $2-\mathrm{mm}^{3}$ samples from at least three diseased trees were taken at the extremities of streaks present in the xylem. Samples were also collected from petioles. All samples usually included contiguous portions of green and discoloured tissues. Samples (with the bark excluded) from symptomless plants that remained sterile on PDA were used as controls. In some cases, samples obtained from diseased plants were incubated on PDA for 12-16 $\mathrm{h}$ before fixing.

\section{Artificial inoculations}

Approximately $1 \mathrm{~m}$ high healthy sumac plants growing in three open or partly shaded areas (Québec region) were used for inoculations. Inoculations were made by cutting with a sterilized scalpel across a drop of inoculum (approximately $1 \times 10^{6}$ conidia $\mathrm{mL}^{-1}$, 
obtained from a culture on PDA) or sterilized $\mathrm{H}_{2} \mathrm{O}$ (control), placed on bark of shoots that was previously surface-sterilized with $70 \%$ ethanol. In one site in 1994, 12 plants were inoculated with isolates obtained in 1993, six with isolate denoted S1-1 and six others with isolate $\mathrm{S} 1-2$; four plants received the control treatment. Sampling was at different intervals from 1-57 d after inoculation (dpi). In 1997, in each of two sites, five plants were inoculated with isolate S1-1 (which caused greater invasion than S1-2 in the previous inoculations) and two with isolate S1-3 (a new isolate obtained in 1995 from another area), and two received the control treatment. Samples were obtained at 2, 4, 7 or 8, 16, and 34 dpi, first at 2 and $5 \mathrm{~cm}$, then between 2-15 cm, and finally from 2-35 cm above the inoculation wound.

Control trees were similarly sampled. The samples selected for examination were limited to those near which the pathogen was re-isolated in pure culture. The prevailing summer weather conditions during the experiments were warm and dry in 1993, 1995, 1997 (early summer) and 2000, a condition which favoured infection, whereas in 1994 it was more humid and cool. In samples from 1994, mostly only those taken at near the end of the experiment (57 dpi) were examined whereas samples collected in 1997 from all dpi intervals were used for examination.

\section{Fixation and embedding}

The 1993-1995 samples were double fixed with $2.5 \%$ glutaraldehyde for $2 \mathrm{~h}$ under slight vacuum, and with $1 \%$ osmium tetroxide at $4^{\circ} \mathrm{C}$ for $1 \mathrm{~h}$ at room temperature. The other samples were fixed in a $2.5 \%$ mixture of glutaraldehyde and paraformaldehyde and subsequently with reduced osmium (Tamaki and Yamashina 1994). Embedding was in Epon 812.

\section{Light microscopy}

Sections (0.5 to $1.0 \mu \mathrm{m}$ thick) were cut from the Epon-embedded material using a glass knife, mounted on slides, and stained with a commercial solution of toluidine blue and basic fuchsin. Three or four contiguous sections from each sample were examined with a Polyvar (Reichert-Jung, Vienna, Austria) microscope.

\section{Electron microscopy}

Ultrathin sections (straw colour), made with a Reichert Ultracut II, were stained with uranyl acetate and lead citrate before examination with a Philips 300 transmission electron microscope at $80 \mathrm{kV}$. At least two samples from each sampling date and ordinarily two sections from each sample (five for cytochemical tests) were examined.

\section{Cytochemical tests}

The exoglucanase-gold complex. The purified enzyme (kindly provided by Dr. Colette Breuil, University of British Columbia, Vancouver, BC, Canada) was prepared according to a previously described procedure (Ouellette et al. 1995), using a colloidal gold particle size of approximately $15 \mathrm{~nm}$ (Frens 1973). Briefly, ultrathin sections were floated for 5 min on a drop of PBS + PEG 20000 (0.02\%) at $\mathrm{pH} 6.0$ and then incubated for $30 \mathrm{~min}$ on a drop of the exoglucanase-gold complex. Specificity was assessed by the following control tests: 1) incubation with the exoglucanase-gold complex previously saturated with $\beta-1,4-D$-glucans from barley at the rate of $1 \mathrm{mg} \mathrm{mL} \mathrm{m}^{-1}$; 2) incubation with the non-complexed exoglucanase followed by incubation with the goldcomplexed exoglucanase.

Gold-complexed monoclonal antibodies (mabs JIM 5 and JIM 7). These mabs to detect pectin substrates (which were kindly provided by Dr. R. Keith, Long Ashton Research Institute, UK) were used as previously described (Rioux et al. 1998).

Gold-complexed WGA to detect chitin. An indirect labelling method with wheat germ agglutinin (WGA) was followed as previously described (Ouellette et al. 1995). Sections on nickel grids were incubated on $25 \mu \mathrm{g}$ of WGA per $\mathrm{mL}$ of PBS followed by exposure to an ovomucoid-gold complex ( $\mathrm{pH} 4.95$ in PBS-PEG). Control tests included omitting the lectin in the procedure or neutralizing it with $\mathrm{N}$-acetylchitotriose. Both compounds were from Sigma (St. Louis, MO, USA).

\section{RESULTS}

Extrinsic elements and matter in vessel lumina Control samples. Tissues of control plants are shown in figure $1 \mathrm{a}$ and $1 \mathrm{~b}$, showing respectively: 1) first year's growth xylem, of a region with mostly small vessel elements arranged in radial rows and of another region with more concentrated, larger vessels. A thick medullary sheath containing strongly stained cells borders a voluminous pith region, in which is illustrated one of the laticifers it may contain; and 2) early secondary xylem displaying large vessel elements, one with a tylosis initial, and small paratracheal cells and long uniseriate ray cells. Some fibres also contact vessel elements. In both cases, injection wounds and/or sample manipulation have occasioned localized, slight splits in the middle lamellae, but those were free of any inflowing material.

Overview, invasion of vessel lumina. The following observations pertain either to inoculated samples or less often to naturally infected material, but in most instances in both types of samples observations were comparable. Some vessel elements, in line with the inoculation point, became partially or completely occluded with heterogeneous matter, some corresponding to latex (as illustrated later on), and including fungal cells of various sizes (Fig. 1c). Passage of the pathogen from one vessel element to another was through pit membranes (Fig. 1c). Opaque matter lined vessel walls (denoted hereafter as VWLM and described in the following subsection). Many fungal cells near the inoculation point (some likely from the inoculum) had dense content (not illustrated), whereas other elements enclosing opaque, granular bodies were delimited by opaque bands that were seemingly confluent with the VWLM (Fig. 1d); these differed from tyloses which generally occurred in vessel elements throughout the invaded xylem. In control samples, some tyloses also formed in vessel elements near the injection wound. At increasing distances from the inoculation point and also laterally from the first invaded vessel elements, thus likely corresponding to more recently deposited ones, only few of these contained occluding material and elements 


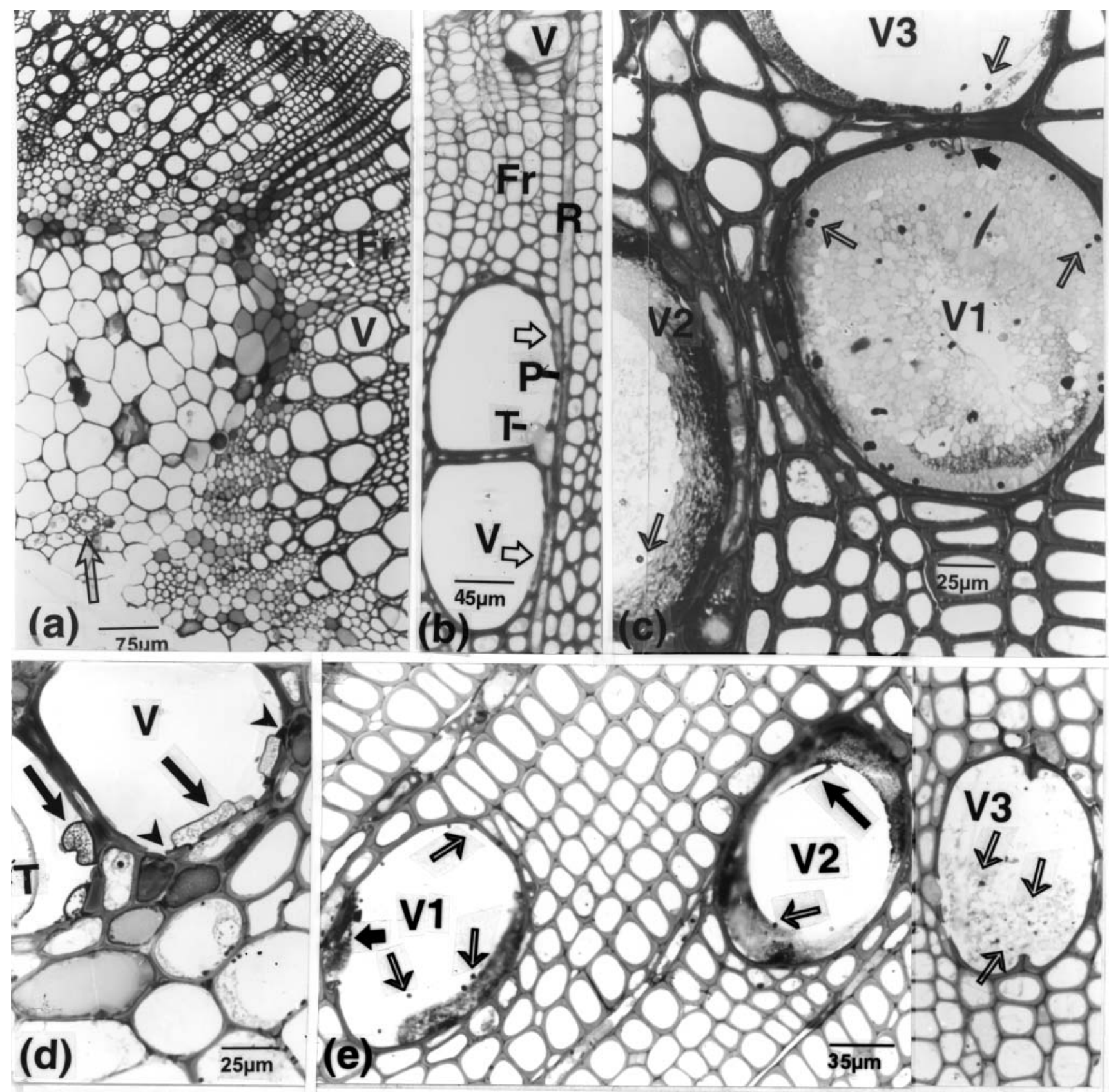

Figure 1. Inoculated samples. Light microscope observations. (a, b): $\mathrm{H}_{2} \mathrm{O}$ injected. First year growth and early secondary xylem, respectively. (a): V-elements of unequal diameters, ring or diffuse porous in parts, some contacting fibres or adjoining uniseriate ray cells. Medullary sheath cells with densely stained content border the pith containing a laticifer (arrow). (b): shows small P-cells, adjoining V-wall portions with only primary walls (arrows), long cells of uniseriate rays, and adjacent fibres. A tylosis bud is visible. (c): in $\mathrm{V} 1-\mathrm{V} 3,5 \mathrm{~cm}$ from the point of inoculation, presence of F-cells (light arrows), one crossing from V1 to V3 via a pit membrane (dark arrow), close to an intercalary, small P-cell. Latex-like matter in V1 or amorphous material in V2 and V3. (d): rounded or rectangular bodies (arrows), distinguishable from the tylosis, confluent with opaque matter on the $V$-wall (arrowheads) are delimited by thin bands circumscribing opaque particles. (e): a mount from two different sections. V-elements near the cambium region contain small particles (light arrows), free in V-lumina, bordering vessel wall or occluding material (V1 and V2), or included in a kind of reticulum (V3). The long dark arrow = a tiny filament, and the short dark arrow, a band connected to a larger body. Fr, fibre; P, parenchyma; R, ray cell; $T$, tylosis; $V$, vessel. 

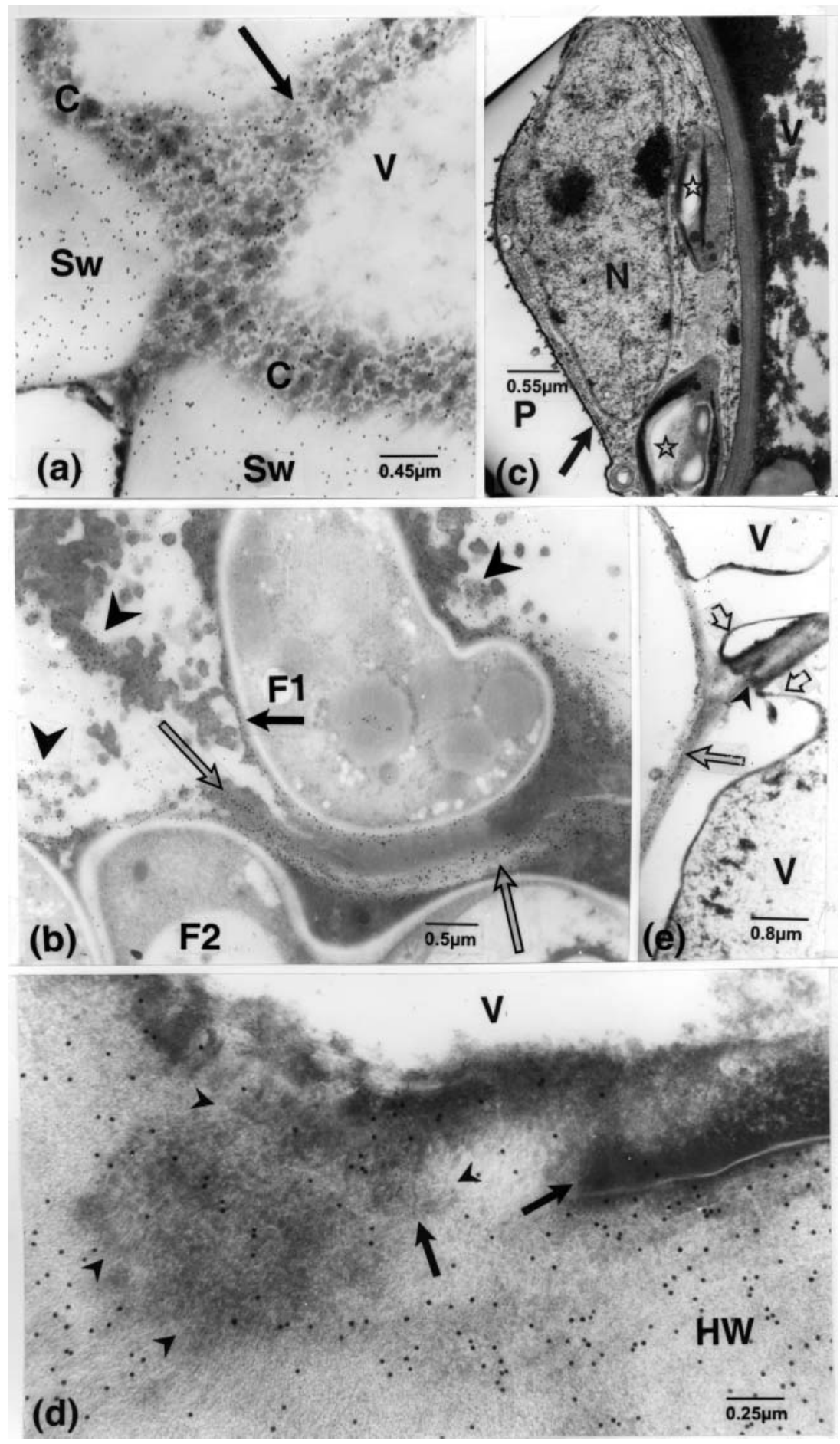

Figure 2. (a, b): Naturally infected samples (NIS). Labelling for cellulose. (a): labelling is clearly associated with many blobs of opaque matter lining the visibly altered Sw and or extending into the V-lumen. (b): labelling, as in a, is also associated with many opaque masses (arrowheads), many in continuity with labelled lucent host wall (light arrows). Most of the gold particles located close to the F1 cell wall also overlay lucent material (dark arrow). (c): inoculated sample. 2 dpi. A V-element with large amounts of dense, opaque material. The tonoplast (arrow) in the adjoining parenchyma cell is thickened and the amyloplasts (stars) show opaque bands and plastoglobuli. (d): NIS. Labelling for cellulose. A host wall (part of a thick vessel primary wall, see Fig. 1b) contains masses of opaque matter (arrows) extending from the wall lining material. Structures of filamentous appearance, delimited by opaque lines (arrowheads), are discernible in this matter, free of gold particles except where it pervaded the host wall. (e): from an IS, labelling with JIM 5 for pectin. Only the middle lamella (long, light arrow) and a band in the pit membrane (arrowhead) are labelled; this band is confluent with the unlabelled V-wall lining material (short, light arrows) in adjoining vessel elements. C, lining on vessel wall; F, fungus; HW, host wall; N, nucleus; P, parenchyma; Sw, vessel secondary wall; V, vessel. 
ascribable to the pathogen (Fig. 1e), whereas thin to thick VWLM layers characterized many other vessels. In naturally infected samples, in comparison, most vessel elements did not contain any large amount of occluding material, but they generally displayed layers of VWLM (see below).

As also shown in naturally infected samples, some vessel elements contained many opaque celluloselabelled clumps of opaque matter that were confluent with similar ones apposed to vessel walls (Fig. 2a). Similarly labelled material was observed to be associated with altered secondary walls in contact with or close to pathogen cells (Fig. 2b). Other opaque material of a fibrillo-granular appearance mixed with small and larger opaque bodies also accumulated in large amounts in some vessel elements (Fig. 2c). Some, often thick, more homogeneous VWLM did not label for this substrate, but it was at times covered by gold particles of the probe when components radiating from layer lining the vessel wall extended into it (Fig. 2d). Likewise, the masses of opaque matter and the VWLM did not label for pectin, except in regions where it extended across pit membranes, contrary to the precise labelling of middle lamellae (Fig. 2e). In some vessel lumina, however, large amounts of moderately opaque material labelled for pectin (Fig. 3a); similar masses of material displaying numerous fibrillar structures were also strongly labelled (not illustrated). Still, in other situations, traces of pectin-labelled fibrils were distinguishable, mixed with large amounts of other heterogeneous matter, often in proximity of labelled pit membranes (Fig. 3b), or labelling was associated with even more compact and abundant material apposed to vessel walls, but different from the VWLM mentioned above, and intermingled in the vessel lumen with blister-like networks (Fig. 3c). Labelling in these cases was clearly comparable to that of the middle lamellae, the pit membranes and the adjoining parenchyma cell protective layer. Blobs of chitin-labelled opaque material also occurred in the periphery of paratracheal parenchyma cells, seemingly related to degraded products of that layer (Fig. 4a).

Whereas the bands forming the blisters just mentioned could have been related to some of the latex in vessel lumina, other different networks, formed of intertwining membranous structures associated with small particles, were also noticeable in vessel lumina (Fig. 4b). Bands of a similar appearance were also observed in a variety of situations, as shown hereafter.

Characteristics of the VWLM. In this section, references to the occurrence of material lining walls of vessel elements will be limited to those lacking components attributable to latex, although VWLM may also have occurred therein, as mentioned above.

A first point to consider is that the layer of VWLM may be very thin and thus would not be easily detectable in light microscopy, as would have been the case for Figure 4c. Similarly, the bands confluent with that delimiting the element illustrated in this figure would not be perceivable. It is noteworthy, here also, that the bands delimit lucent chitin-labelled layers, circumscribing stretches of cytoplasm-like matter. Gold particles, in high concentrations over these layers or over the lucent mass at the extremity of the part enclosing both stretches, are absent over these cytoplasmic structures and the surrounding amorphous matter.

With the exception of the noteworthy case just mentioned, the features described below were as common in inoculated as in naturally infected samples, and considered to be often complementary. Thus, the thickest VWLM layers, in more advanced infections, was often stratified with alternating thin, opaque and more lucent layers, the number of which varied not only between vessel elements but also in the same vessel element (Fig. 5a). The intercalary or outermost opaque layers generally occurred as thin bands with which were frequently confluent vesicular-like bodies (Fig. 5b). Material similar to the VWLM occurred only exceptionally in paratracheal cells but, in these instances, connections of this material between these cells and that in the vessel element through the pit membrane were visible (Fig. 5b). Similarly, interconnections of the VWLM from one vessel element to another were frequently indicated by its continuity via pit membranes (Fig. 5c). Chipping of vessel walls and notches in pit membranes of halfbordered pits were likewise associated with the VWLM (Fig. 5d).

Other types of VWLM occurred as bands intermingled with the compact lining matter, from which extended strands into vessel walls (Fig. 5e, f). Penetration of this matter into these walls was indicated by their being covered with gold particles of the cellulose probe (Fig. 5e). In severe cases, walls were strongly permeated and noticeably altered in association with this type of VWLM (Fig. $5 \mathrm{~g}$ ). The bands being part of this VWLM were somehow similar to the often wavy bands that frequently encompassed typical (Fig. 5h) or irregular (Fig. 6a) fungal elements. The peculiar features of these irregular elements were their being delimited by somewhat diffuse striated and by often single wall layer and with their residual content appearing as networks of membranous structures and associated vesicular bodies (Fig. 6a, b). Discontinuity in the walls of these elements were also visible, and matter of the VWLM, with which were also associated vesicular bodies, was confluent with these elements (Fig. 6a); some of these bodies seemingly corresponded to outgrowths of the VWLM-layer or cross sections thereof. Similar bodies occurring in elements that were solely delimited by membranouslike structures likewise corresponded to possible cross sections of infolds of these structures (Fig. 6c, d). These tiny elements, demarcated by paired opaque bands, often extended long distances along vessel walls, confluent with or neighbouring other larger, similarly delimited elements (Fig. 6d); in these, one of the bands frequently merged with a more diffuse layer displaying fine, filamentous structures, and which, when apposed to vessel walls, impinged on them. Indications that similar elements were connected to typically delimited fungal cells (Fig. 6e) or to larger elements, also delimited by thin bands and containing cytoplasmic structures (Fig. 6f, inset A), were obtained. Vessel wall penetrating peg-like structures, locally delimited by a distinct membrane and elsewhere by a diffuse layer having impinged on the vessel wall (Fig. 6f, inset B), were at times connected to these larger elements. 


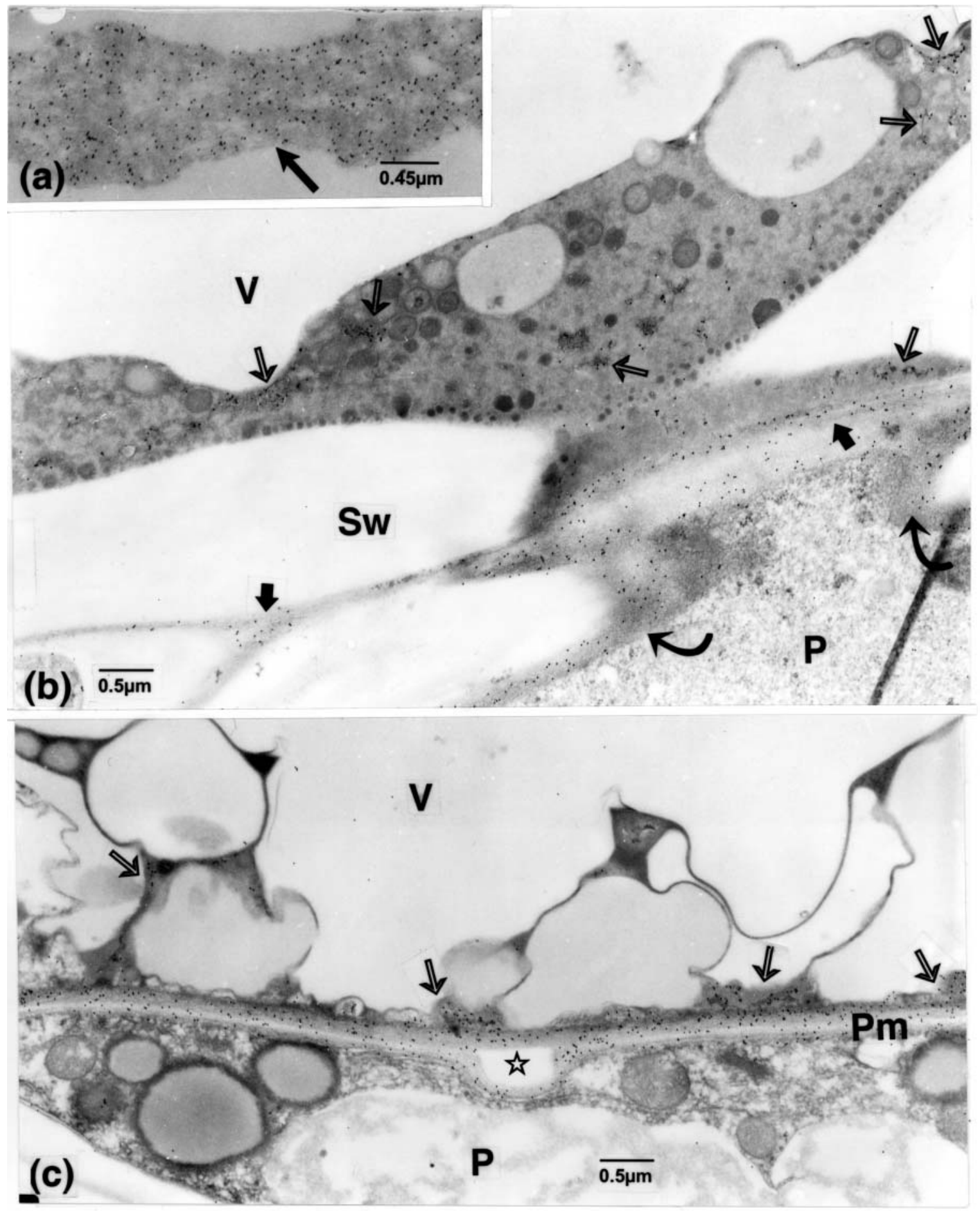

Figure 3. Inoculated samples. Labelling for pectin with JIM 5. (a): shows a stretch of uniformly labelled material (arrow), except for lighter areas, late infection. (b): early infection. Gold particles are localized over the mostly opaque middle lamella and pit membrane (short, dark arrows), the protective layer (curved arrows) and patches of fibrillar structures (light arrows) in the material apposed to the V-wall. (c): gold particles are present over the long Pms and the protective layer surrounding a small isthmus of secondary wall (star), and masses of moderately opaque matter (arrows) present on the pit membranes or between blister-like bodies, later infection. P, parenchyma cell; Pm, pit membrane; Sw, vessel secondary wall; V, vessel. 


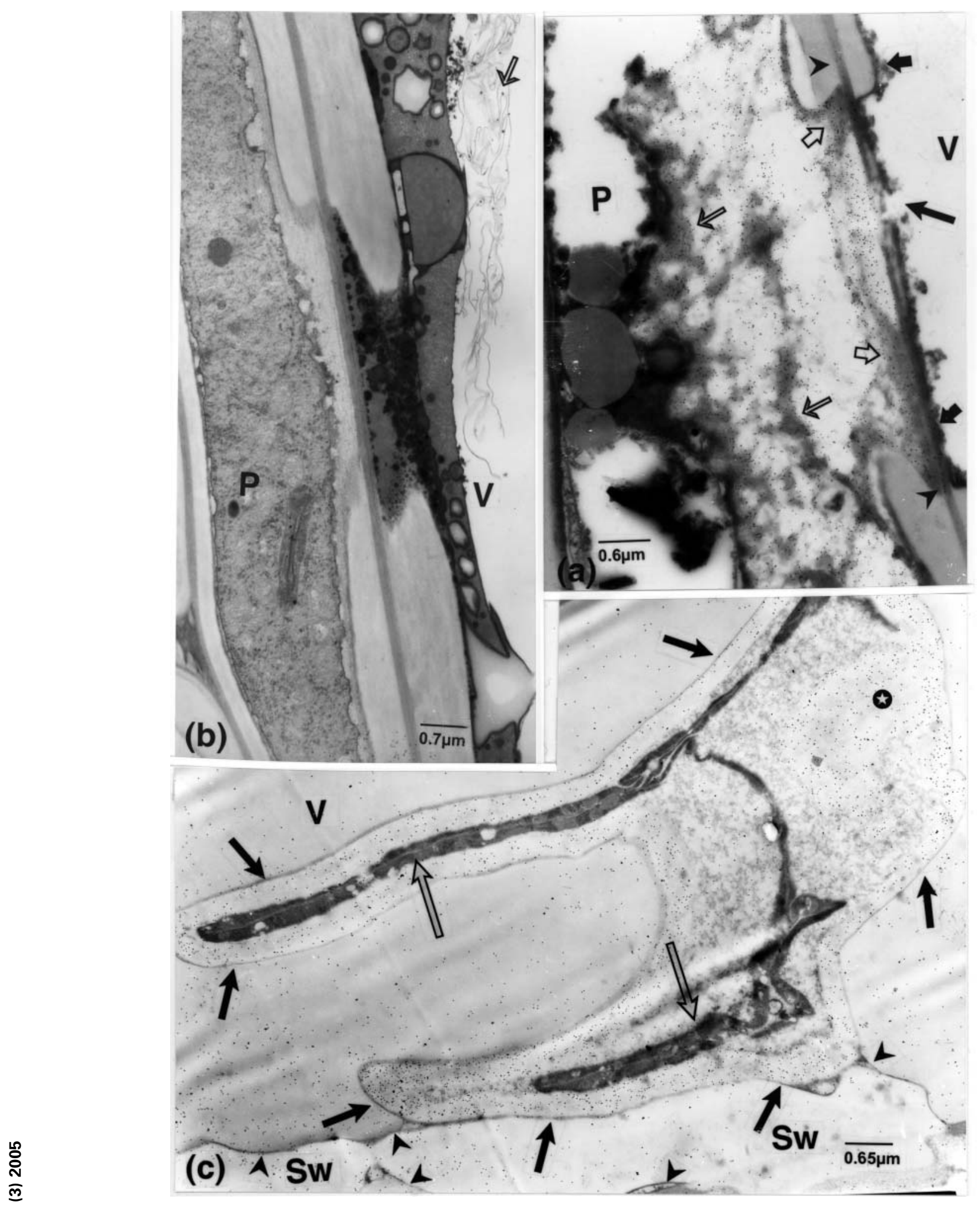

Figure 4. (a): Naturally infected sample (NIS). Labelling for pectin. The altered protective layer (large, light arrows) and the masses of opaque matter (thin, light arrows) in the P-cell periphery are strongly labelled, the middle lamella slightly so (arrowheads), and the V-wall lining material is not labelled (short, opaque arrows); a gap is visible in the pit membrane (long, opaque arrow). (b): inoculated sample. 2 dpi. A network of membranous structures, some associated with small particles (arrow), overlay other matter in a V-lumen, in a region invaded by the pathogen. (c): NIS. Labelling for chitin. In a V-lumen, a U-shaped element displays thin interconnected stretches of cytoplasmic matter (long, light arrows), confined by labelled wall-like layers. These are bound by an opaque band (dark arrows), similar to and continuous with the V-wall lining material (arrowheads). A mass of labelled matter (star) also occurs at one end of the element. P, parenchyma; Sw, vessel secondary wall; $V$, vessel. 

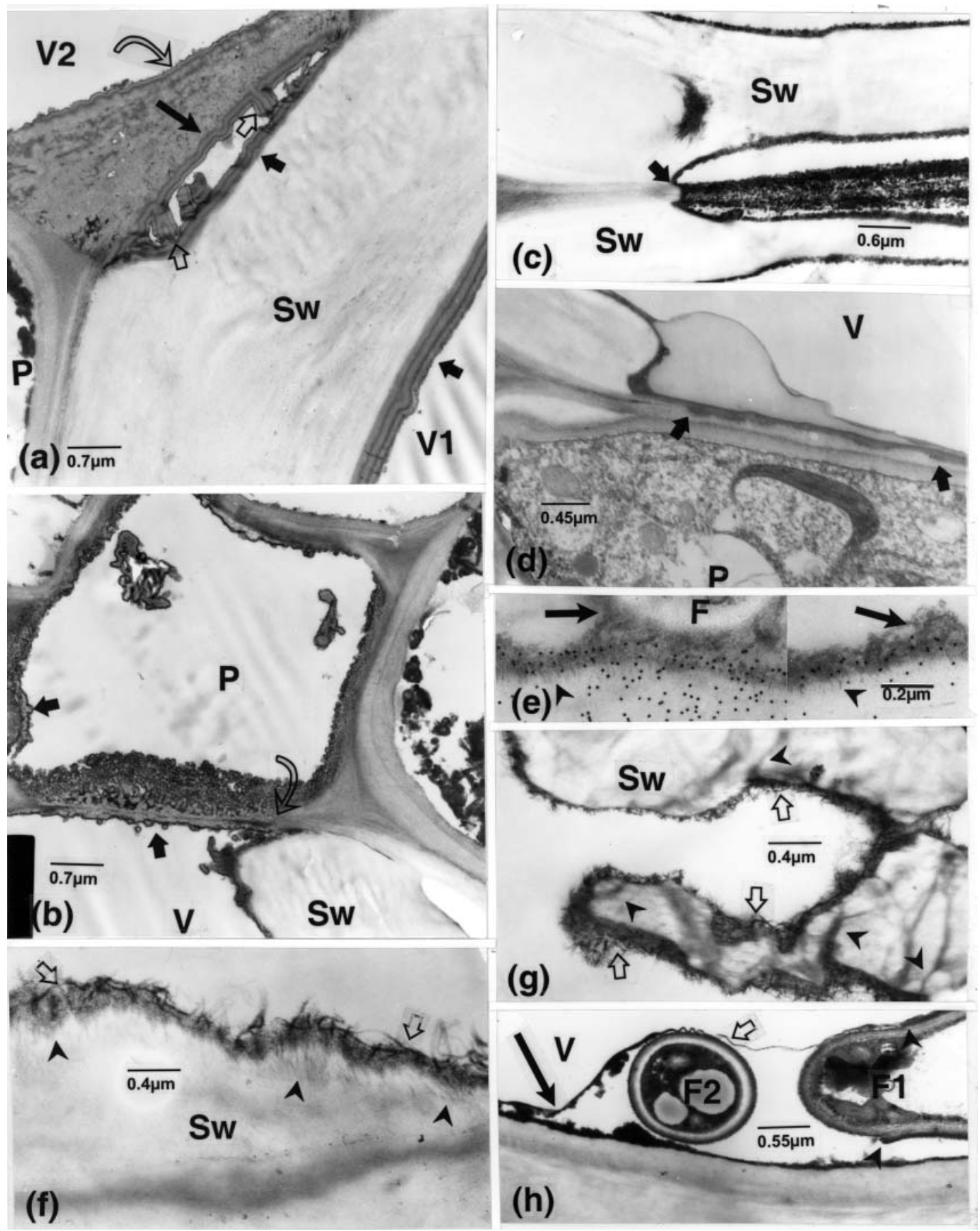

Figure 5. Naturally infected samples, except d, inoculated sample. (a): V-walls are covered with a thick layer having alternating less and more opaque bands. These are six-layered (short, dark arrows) along the Sw-walls, five-layered (long, dark arrow) on the pit membrane side and twice that number in the infolds (light arrows) crossing the pit chamber, and three-layered along the pit membrane facing V2 (curved arrow). (b): vesicular-like bodies (arrows) are connected to the VWLM extending as an opaque band over the locally impregnated and seemingly displaced pit membrane (curved arrow). Material similar to the VWLM (arrow in P) and bodies contour the P-cell, including the pit membrane. (c): the VWLM is confluent from one V-element to another via the altered pit membrane (arrow). (d): VWLM (arrows) occurs in notches in the membrane of a half-bordered pit. (e): labelling for cellulose. Gold particles overlay the VWLM, from which extend opaque strands (arrowheads) into the V-wall, but are absent over the Fextracellular matter or over that more remote from the wall (arrows). (f): many opaque, filamentous-like bands are present in the VWLM and opaque bands extend from it into the wall (arrowheads). (g): a V-wall is much altered in association with matter similar to that in $\mathbf{f}$ (arrows) and opaque bands connected to it pervade the wall (arrowheads). (h): a thin, membranous band (light arrow) extends from the extracellular layer of cell F1, wavy around and joining the VWLM (dark arrow); discontinuities in walls of this cell are visible (arrowheads). F, fungus; P, parenchyma; Sw, vessel secondary wall; V, vessel; VWLM, vessel wall lining material. 


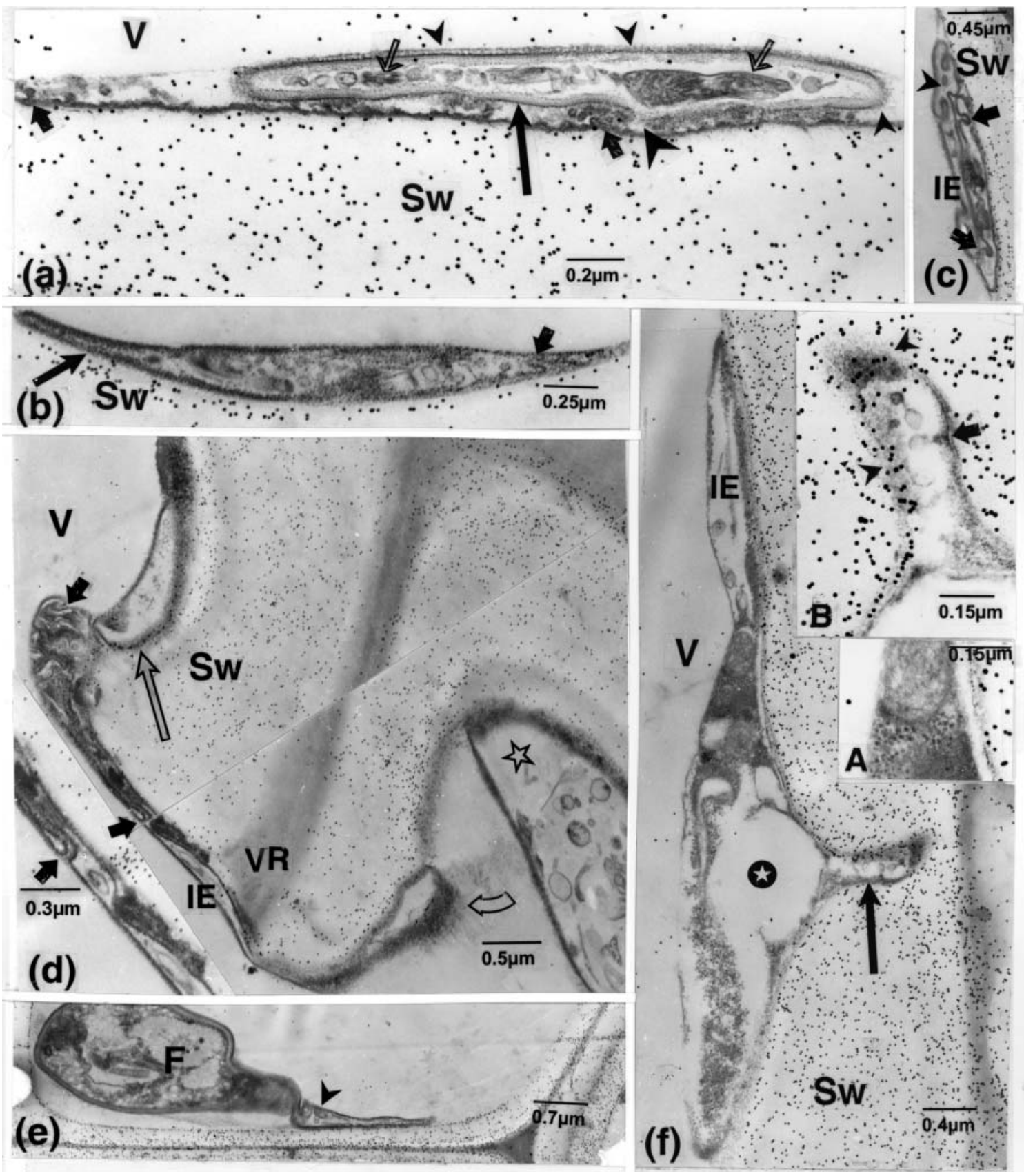

Figure 6. Naturally infected samples. Labelling for cellulose. (a): a small F-element (long, dark arrow) along a V-wall is demarcated by an opaque band bordered inside by a light layer and outside, mainly on the V-lumen side, by spaced filamentous structures connected to the band (small arrowheads). The large arrowhead = an apparent discontinuity in the F-element wall; the short dark arrows $=$ infolds in the V-wall lining layer. The intercalary vesicular-like structures between this layer and that on the V-lumen side, bypassing the element, are structurally similar to the bulges of the layer; and the thin, light arrows = networks of membranous structures associated with vesicular-like bodies in the element. (b): an element (long arrow) analogous to that in a, but delimited by only an also infolded layer (short arrow) of a striated appearance. (c): an IE apposed to a V-wall is delimited by opaque bands, infolded at several places (arrows); circular bodies (arrowhead) in these may correspond to cross-sections of the infolds. (d): an IE contouring a vessel rim. The IE-delimiting bands are also infolded (dark arrows), one shown enlarged at the left of label IE. Gold particles overlay the opaque delimiting band, impinging upon the vessel wall (light arrow). A similarly delineated larger element (star) contains vesicular structures. Flaring portions of the bands display fine filamentous-like structures (curved arrow). (e): an IE-like element (arrowhead), not showing a lucent wall, is connected to a larger F-cell having such a wall. (f): an element (IE), containing vesicular structures and fine matter, is confluent with an element (star) containing opaque particles of ribosomal appearance and traces of membranous structures (enlarged portion, inset A). The host wall penetrating peg-like structure connected to the element (arrow, inset B, an enlarged portion) is delimited by a membranous band on one side (arrow) and in other regions by fine structures (arrowheads) overlaid by gold particles. F, fungus; IE, irregular element; Sw, vessel secondary wall; $\mathrm{V}$, vessel; VR, vessel rim. 


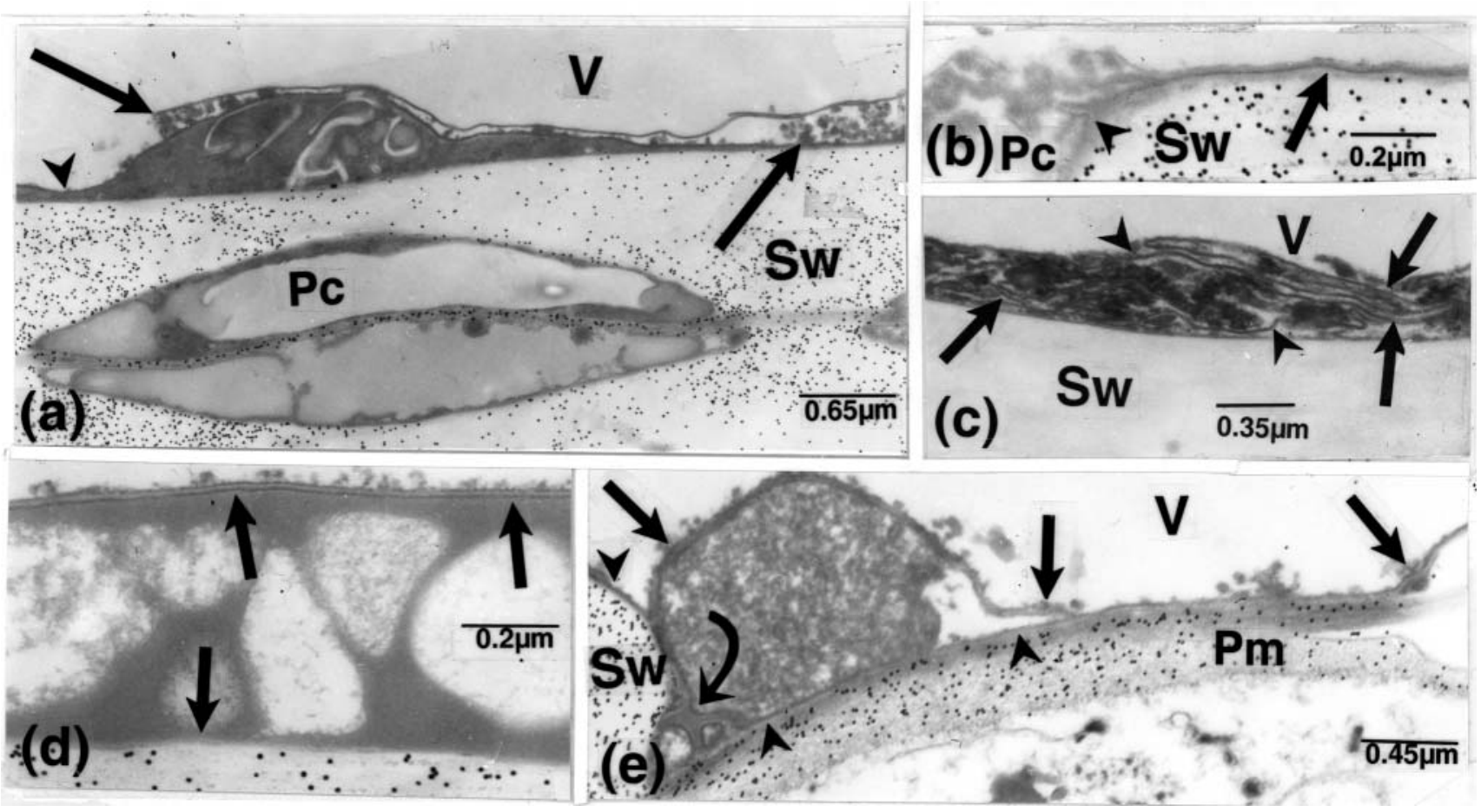

Figure 7. Inoculated samples. Labelling for cellulose, except c, unlabelled. Gold particles occur only over host wall components. (a): paired, separated bands (arrows) circumscribing opaque bodies, overlay some other type of material, but at a site of discontinuity in one of the bands, this material is covered by only a single band (arrowhead). (b): a single band (arrow) (a part of a much longer one) included in fine material appears to pair with a similar band at the pit border (arrowhead). Both the bands and fine matter merge with bodies of homogeneous matter in the pit chamber. (c): three or four pairs of opaque bands (arrows) are mixed with opaque material. Intertwining single bands are visible at sites (arrowhead). (d): a large mass of fine matter surrounding vacuole-like areas, apposed to the V-wall, is delimited on both sides by paired bands (arrows). (e): an opaque mass of homogeneous matter, present over a pit membrane, is surrounded by opaque bands that extended a long distance over the membrane and the adjacent V-wall. The bands are paired at sites (straight arrows), joining to form a claw-like structure (curved arrow), but appear single at other places (arrowheads). Pc, pit chamber; Pm, pit membrane; Sw, vessel secondary wall; $V$, vessel.

The elements described in figure 6 were from naturally infected material. Parallel observations of inoculated samples were made, in which occurred similar, equidistant or unequally spaced, paired bands encompassing opaque bodies or circumscribing other type of material apposed to vessel walls (Fig. 7a-e). In early infection, fungal cells were regularly observed in these invaded vessel elements (not illustrated), but less frequently in the more advanced infection stages. The bands, in these samples, often extended over noticeable distances as a single unit, which farther on coalesced with other bands or matter (Fig. 7b-e). Intertwining single and paired bands were also mixed with opaque matter forming a thick layer on vessel walls (Fig. 7c). In some instances, the layer apposed to these walls was thinner than the outside one, but fusion of both layers was evident, or oblique sections thereof made them appear as a compact layer (not illustrated).

The band-delimited elements just described, contrary to typical cells, lacked an inner lucent layer. However, by testing for chitin, the WGA probe frequently attached erratically to them, and in a few instances to diagonal lucent bands associated with opaque bodies (not illustrated).

\section{Host wall invasion and alterations}

The following observations mostly concern naturally infected material representing different stages of infection, the most recent ones being related to samples taken at the tip of advancing streaks, with particular attention being given to peculiar modes of tissue colonization by the pathogen. Thus, some host wall invasions were characterized by fungal cells appearing to have penetrated in a frontal manner wide portions of the wall (Fig. 8a-c); the fungal cell then appeared to have some atypical content. Portions of the fungal cell wall in these situations were pervaded by filamentous structures, and/or were seemingly discontinuous and at times very abruptly (Fig. 8a-c). Host wall penetration also occurred by means of tiny peg-like structures which also apparently were not bound by a distinct wall, as compared with the fungal cells with which they were confluent (Fig. 8d). In many cases, a loss of labelling of host walls for cellulose in contact with these fungal elements was noted (Figs. 8d).

Direct penetration of primary and secondary walls of parenchyma cells and fibres by pathogen cells, from within a host cell or from an intercellular area, was of common occurrence, with host wall-pathogen 
cell interfaces being characterized by many noteworthy features. Thus, some fungal cells did not label for chitin but opaque matter surrounding them did, whereas others were included in matter containing vesicularlike structures and delimited by a thin layer (Fig. 9a), indicating that these cells might have formed as endocells. A feature possibly related to this aspect was that when pathogen cells were included in host walls or in close contact with them, the fungal cell walls were often irregular or absent (Fig. 9b, c); also, these walls were frequently pervaded by filamentous struc- tures extending into the surrounding medium or connected to an extracellular opaque layer or sheath.

Some host wall-penetrating peg-like elements, stemming from masses of matter apposed to host cell walls and locally divided by bands of lucent, slightly labelled material, were seemingly not wall- or even membrane-delineated elsewhere, as, likewise, was not similar confluent matter affixed to the cell wall (Fig. 9d-g); thin bands also reached from this matter into the host wall (Fig. 9e). As shown at higher
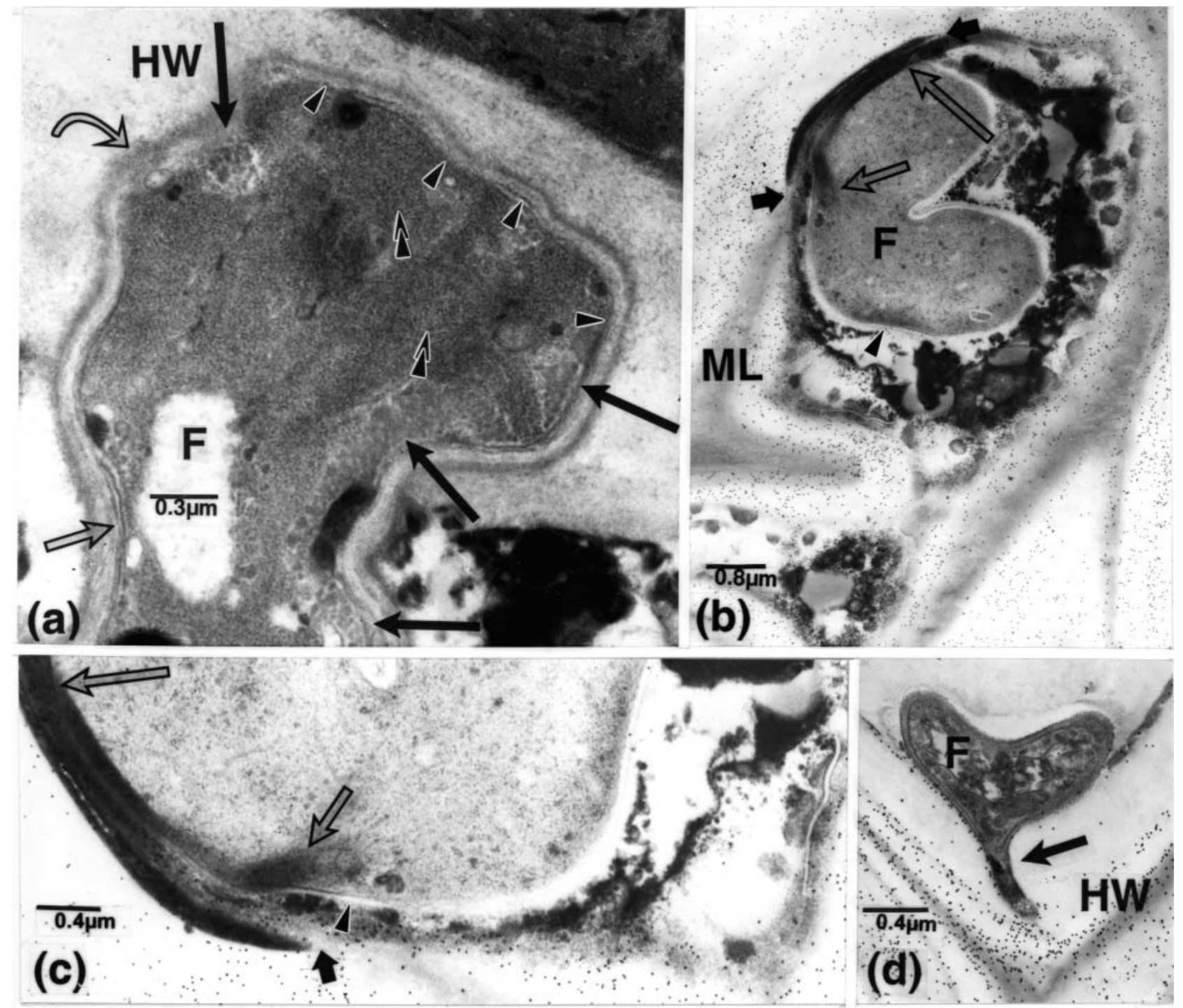

Figure 8. Naturally infected samples. (a): a F-cell having penetrated a host cell wall, marked by a long fungal/host wall interface. The cell mainly contains small particles, some showing a lucent core (superimposed arrowheads). Masses of coarser components (dark arrows) locally border the cell periphery, as locally do paired membranous structures (light, straight arrow). A wall is seemingly lacking over a cell portion (curved arrow), in which as well as in the distinct wall occur arrays of filamentous structures (arrowheads). (b-d): labelling for cellulose. (b and enlarged portion, c): the same types of arrows point to similar areas and features, in each illustration. The F-cell contains, along a portion having seemingly cut across a host wall including the pit membrane (dark arrows), a band of opaque-appearing material (short, light arrow). The F-wall is very thin (arrowheads) or confounded with the opaque matter and/or host wall (long, light arrow), part of which is overlaid by gold particles. (d): a peg-like structure (arrow), in a host wall, is lacking limiting walls along its tip-end. Compared with the strongly labelled middle lamella and adjoining host walls, the secondary wall in contact with the F-cell is almost free of gold particles. F, fungus; HW, host wall; ML, middle lamella. 


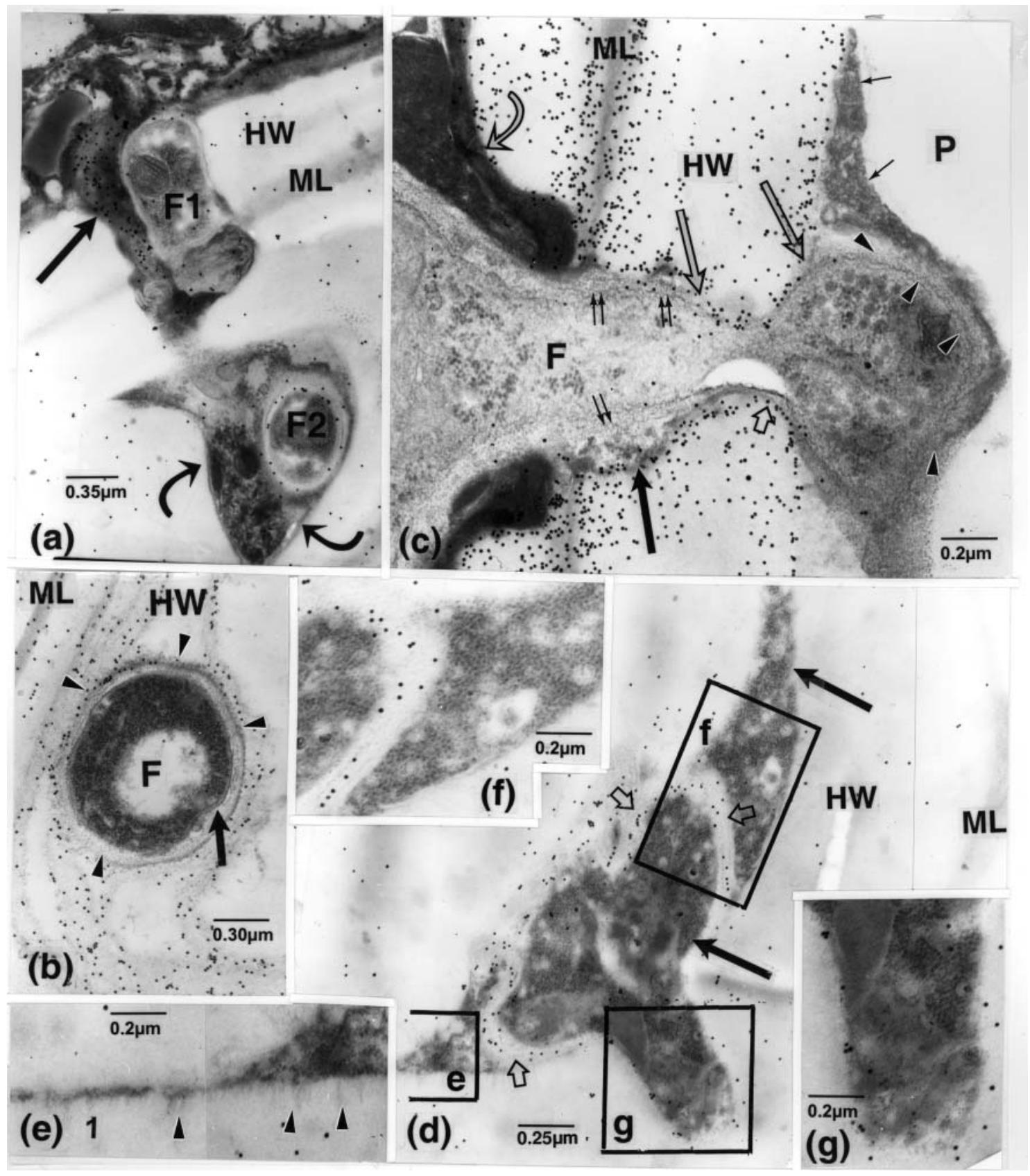

Figure 9. Naturally infected samples. (a): labelling for chitin. Concentrations of gold particles occur over the stretch of mostly opaque matter (straight arrow), adjoining the unlabelled cell F1. The cell F2, with a barely labelled wall is included in material, connecting across the cell wall with other similar material surrounding cell F1. This material, delimited by distinct bands (curved arrows), contains opaque bodies and vesicular-like structures. (b, c): labelling for cellulose. (b): an F-cell, included in altered host wall, has its walls pervaded by filamentous structures (arrowheads), and its margin locally overlaid by some gold particles. An inner layer, thicker than the plasma membrane, contours some matter (arrow) in the cell periphery. (c): fine filamentous structures (single, thin arrows), some visible in cross sections, are discernible in the opaque material surrounding the F-cell, some extending across its wall (arrowheads). The F-wall in the cell portion having penetrated the host wall is either thin and imprecise (between long, light straight arrows) or discernible as a thicker band (dark arrow) confluent with that extending around the cell (short, light arrow) in the parenchyma cell side; these layers are covered by gold particles. In more seemingly thicker wall portions, filamentous structures extend from the fungal cell periphery into masses of opaque matter (double small arrows). Differences in opacity are apparent between the layers of opaque matter apposed to the P-cell walls and that surrounding the F-cell portion (curved arrow). (d): labelling for chitin. e-g are enlarged portions, corresponding to the regions labelled by the same letters. A mass of cytoplasmic matter (dark arrows) is divided by lucent, slightly labelled layers (light arrows). The element extremities (one extending as a part of e) and the confluent host wall-penetrating peg appear to be unbound. As shown in e-g, this element contains mostly particles of ribosomal appearance and a few other masses of nearly homogeneous matter. Fine opaque material (arrowheads, in e) extends from the element into the host wall. F, fungus; HW, host secondary wall; ML, middle lamella; $P$, parenchyma cell. 
magnifications (Fig. 9f, g), many opaque particles of ribosomal appearance occurred in these masses.

Pronounced alterations of vessel pit membranes occurred in direct contact or not with fungal cells (Fig. 10a, b); these alterations were characterized by a shredding of the membrane middle portion, unlabelled for cellulose, and by a granulation of the membrane outer portions, strongly labelled for cellulose (Fig. 10a). Pit membrane breakdown-products were seemingly not released into vessel lumina or other empty spaces (except occasionally, see Fig. 2a, b); degradation of the protective layers in adjoining parenchyma cells also appeared as cellulose-labelled bodies that seemingly were not much displaced (Fig. 10c). The hyphae having passed from one vessel element to another, or at times from or into parenchyma cells, were generally of so-called normal diameters, but often narrowed down into microhyphal-like element having thin walls (Fig. 10d). Fungal walls frequently impinged upon pit membranes of either bordered or half-bordered pits, as shown by labelling of these walls for cellulose (Fig. 10c), or by their irregularities and humps fitting notches in host walls (not illustrated). Differences in fungal cell wall thickness and/or in their labelling for chitin were obvious, with the wall portion contacting host walls being almost free of labelling, or with labelling being associated with the opaque external layer (Figs. 10d, 10e 11a). This difference possibly accounted for the unusual number of gold particles of this probe in void spaces close to hyphal cells (Fig. 10d).

The lucent wall layers in other fungal cells (Fig. 11b) did not label for chitin, compared with other nearby, distinctly labelled cells; however, those cells were surrounded by masses and bands of chitin-labelled matter, and thus appeared, as mentioned above, as if they had formed a type of endocell. In contact with latex, which was abundant in some vessel elements, cells had often thin, striated walls that were pervaded by filamentous structures which extended into the surrounding medium, and seemingly also into the latex globules (Fig. 11c). Other cells showed a type of wall desquamation (Fig. 11d). In opposition, fungal cells not contacting latex globules were more intact, seemingly "protected" by "spear" outgrowths of their outer opaque layer (Fig. 11e).

\section{DISCUSSION}

Present observations pertained to elements and associated matter occurring in vessel elements invaded by F. oxysporum f. sp. callistephi and to its mode of tissue invasion. As the disease caused by this pathogen is specific to staghorn sumac, it may be considered of little economic importance. However, the present histopathological study, conducted for the first time on the disease, is considered to add significant fundamental knowledge that can apply to the other wilt diseases we have previously investigated, e.g. Dutch elm disease, Fusarium wilt of carnation and tomato, and verticillium wilt of eggplant (Charest et al. 1984, 2004; Ouellette and Rioux 1992, 1993; Ouellette et al. 1999a, 1999b, 2001, 2002, 2004c, unpublished observations). Thus, a number of new features were observed regarding host wall penetration and alteration, and the morphology and cytology of the pathogen. Other important features are presented in this issue (Ouellette et al. 2005).

Tissue invasion was often favoured by fungal elements having thin or defective walls. This might seem the only means by which the pathogen could have penetrated directly a host wall over a large surface, not surrounded by a zone of lysis (see Figs. 8a, 8b, 9d); a type of phagocytosis may be involved in this case (O'Connell et al. 1984), possibly explaining how foreign material might become incorporated into the fungal cell. Another noteworthy feature was related to the pronounced breakdown of pit membranes, as shreds unlabelled for cellulose in their inner region and as opaque amorphous material labelled for cellulose in their outer one (as in elms, carnation and eggplant, referred to above). This type of alteration might correspond to the so-called swelling of pit membranes (Beckman 1987; Bishop and Cooper 1984), but with rare exceptions that the pit membrane breakdown products were released into the vessel lumen. The occasionally observed opaque celluloselabelled bodies in vessel lumina could have originated otherwise, as they were similar to labelled bodies associated with secondary host wall in contact with pathogen cells (see Fig. 2b). At any rate, these products could be easily distinguished from the VWLM, which was usually unlabelled for either cellulose or pectin. In fact, the pit membranes, intact or degraded, were usually confined by the VWLM, which differed from these products in labelling and in appearance.

Pronounced vessel occlusions were mostly localized and noticeable only near the point of inoculation. The occluding components were very heterogeneous, including latex. However, the presence of latex was seemingly localized in vessels that were severed by the inoculation wound, as it was also observed in control samples. Latex also occurred, however, in newly differentiated vessel elements (as described elsewhere), which may be of importance therein. Present observations have shown its possible deterrent effect on fungal development. This may be the reason why some of the inoculated plants were slow to develop external symptoms.

As in elms and non hosts inoculated with Ophiostoma novo-ulmi (Et-Touil et al. 2005; Rioux and Ouellette 1991; Rioux et al. 1998), some material in vessel lumina was also traceable to tylosis walls in sumac, which also labelled for pectin but, here, the labelled components were more compact and opaque, similar in this respect to labelled protective layers; following their disintegration, these layers yielded pectin-labelled opaque masses, similar to those which labelled for cellulose. Nevertheless, more dispersed labelling for pectin matched fibrillar structures. In plants inoculated with $O$. novo-ulmi, Fusarium (Ouellette et al. 2004c, d; Rioux et al. 1998), or Verticillium in eggplant (unpublished observations), labelling of similar opaque matter for pectin was not observed, even in the vicinity of labelled fibrils. In cases where more compact pectin-labelled material was apposed to vessel walls, it could likely have been associated with traces of host wall residues related to latex production (unpublished 


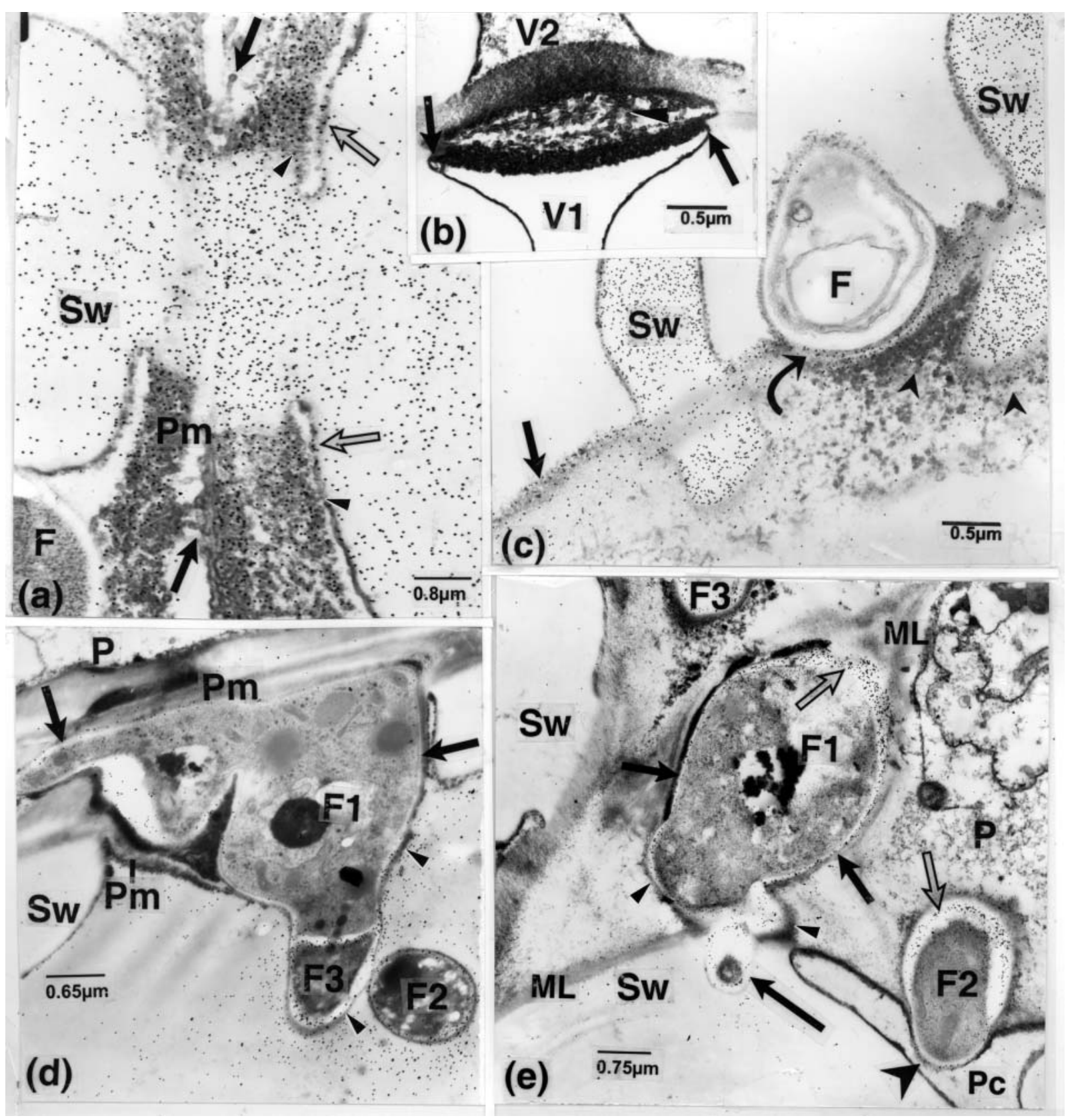

Figure 10. Naturally infected samples. (a): labelling for cellulose. The pit membrane middle portion in both bordered pits is altered shred-like, unlabelled (dark arrows), and the outer portion, visible as blobs of opaque matter, is strongly labelled. The F-cell, the inner Pm and the V-wall lining material, except where it impinges upon the wall (light arrows), are free of gold particles. Fine filamentous structures bridge (arrowheads) this material and the altered membranes. (b): the Pm inner portion (arrowhead) is as in $\mathbf{a}$, and the material lining the walls in both V-elements are interconnected via the membrane (arrows); the Pm inner portion facing V2 is heavily pervaded over a portion demarcated by the extremities of the lining. (c): labelling for cellulose. The wall of the F-cell inflecting a labelled pit membrane is overlaid with gold particles (curved arrow). Blobs of opaque matter (arrowheads), likely released from altered portions of the protective layer, are also labelled. Gold particles occur over an eroded vessel wall portion (straight arrow). (d, e): labelling for chitin. (d): gold particles are almost nil over the thin cell F1 wall contacting host walls and over the thin element connected to that cell and extending into the P-cell (between arrows), in comparison with their high numbers over the F2 and F3 cell walls facing the V-lumen. Gold particles occur over portions of the outer opaque wall layer of cells F1 and F2, and in high numbers in the vicinity of these cells. (e): cells F1 and F3 occur in altered middle lamella and intercellular areas and cell F2 in a P-cell. Lucent layers in cells F1 and F2 are strongly thickened and labelled (light arrows); thinner elsewhere, this layer is slightly labelled in F1 (dark arrows), but not the cell F2 lucent wall portion protruding through the pit chamber, whereas the outside contiguous thin opaque layer of this cell (large arrowhead) is labelled. Opaque bands (small arrowheads), confluent with the outer layer of cell F1 and circumscribing an area labelled for chitin, abut on another similarly labelled area, surrounding a mass of cytoplasmic-like matter (long, dark arrow) present in the vessel wall. F, fungal cell; $M L$, middle lamella; $P$, parenchyma cell; Pc, pit chamber; Pm, pit membrane; Sw, vessel secondary wall including thickenings; V, vessel. 

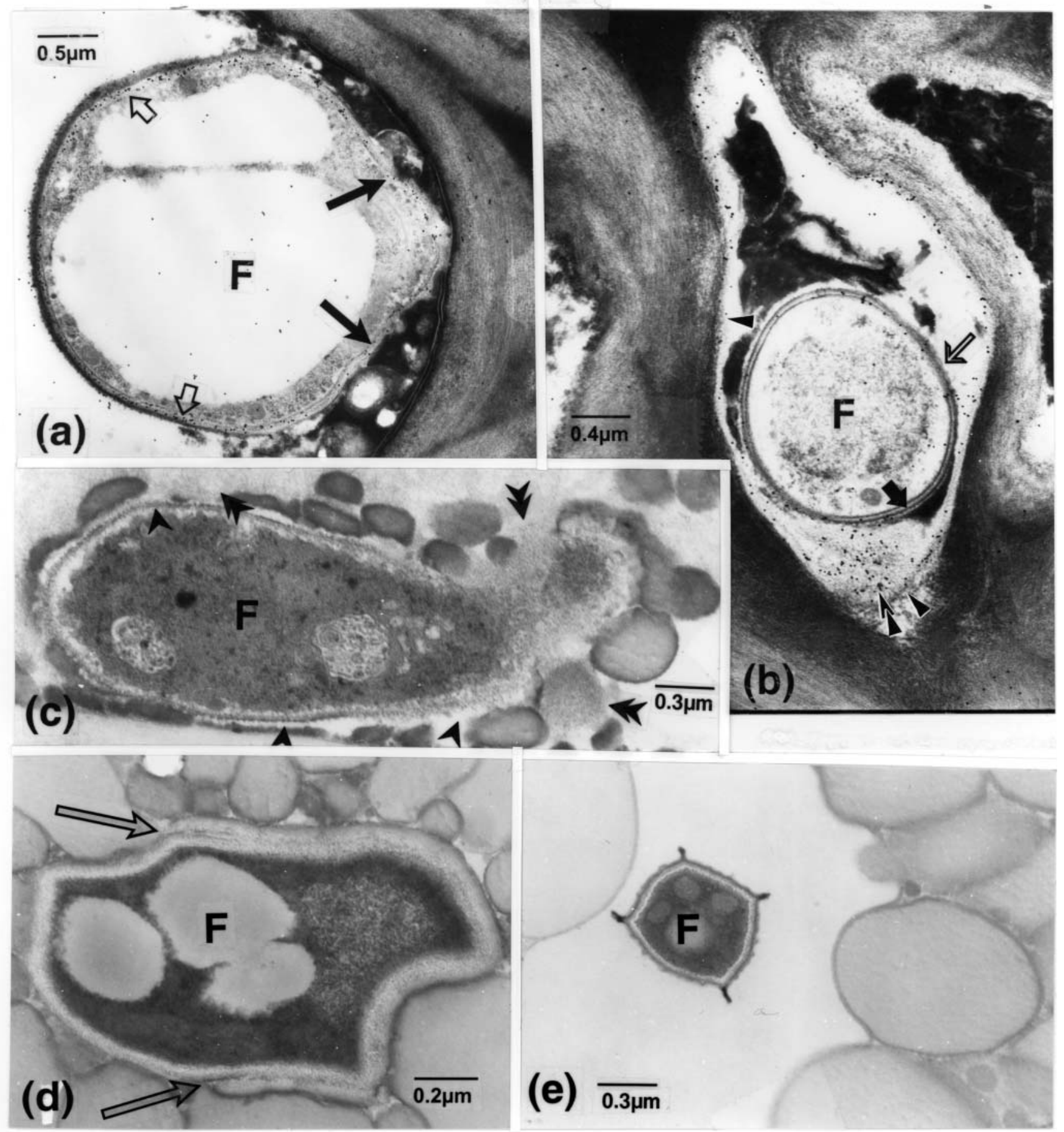

Figure 11. (a, b): Naturally infected samples. Labelling for chitin. (a): the inner lucent and outer opaque F-cell walls are thin or discontinuous and practically unlabelled in the portion close to or contacting host cell content or wall (between dark arrows), contrasting with the confluent clearly labelled layer elsewhere (light arrows). (b): the F-cell is included in an intercellular area bordered by a thin, labelled layer (arrowheads) and adjoining a similarly labelled mound of fibrillar material (the area indicated by superimposed arrowheads reaching the cell, left of the dark arrow). The wall layer of this cell, identifiable as an endocell, is at sites irregular (thin arrow) and unlabelled. (c-e): inoculated samples. (c): the F-cell walls, contacting latex material in a V-lumen, are pervaded by filamentous-like structures (arrowheads), some of which extend into the surrounding medium including the latex (superimposed arrowheads). (d): a fungal cell in close contact with latex globules shows a type of wall desquamation (arrows). (e): a F-cell with spear outgrowths" of its outer, opaque layer, in an area free of latex. F, fungus. 
observations). In line with this possibility, the blisterlike networks in vessel lumina could likewise have originated from latex configurations and differed from the alveolar networks observed in elms infected with Dutch elm disease (Ouellette and Rioux 1992; Ouellette et al. 2004e). However, the networks of thin bands, free and extending into vessel lumina or as part of the VWLM, also occurred and, as the alveolar network in elms, were associated with vessel wall alterations. The association of these often wavy bands and their confluence with or as part of the outer opaque layer of pathogen elements indicates that the bands were not mere artefacts of fixation. The association of opaque particles or other small bodies with these bands or with the VWLM was not frequently observed, but they may be meaningful in the sense that their presence compares with similar situations in the other hosts mentioned above. The intriguing element shown in figure 4c deserves special consideration as it may have formed similarly as microhyphae (Hale and Eaton 1985a, b). Indeed, these authors found that microhyphae were initially not distinctly bound by a wall and developed along a single strand of endoplasmic reticulum and traces of other matter. The labelling for chitin of the thick lucent mass associated with these stretches of cytoplasm may appear problematic, but may be analogous to the situations shown in figure $11 \mathrm{~b}$ and in Ouellette et al. (2001).

The elements, denoted as irregular, apposed to vessel walls, were also similar to those illustrated in carnation (Ouellette et al. 2004a). The peculiar characteristics of these elements help to shed light on their nature and possible origin. First, some of these were linked to typical fungal cells, others either contained particles of ribosomal appearance, vesicular-like bodies and/or membranous structures, whereas in tests for chitin some reacted positively; second, pegs extended from the elements into vessel secondary walls; and third, some of the element limiting-bands impinged upon these walls, directly or by means of filamentous structures, as for the VWLM itself. In parallel, similar structures were again found to be connected to fungal cells pervading their walls and extending into the surrounding medium including host walls. These observations are in support of those made of other fungal wilt diseases and their pathogens, including Dutch elm disease, Fusarium infection in tomato and carnation, and Verticillium in eggplant (Charest et al. 2004; Nicole et al. 1994; Ouellette et al. 1999a, 1999b, 2002, 2004a, 2004b, 2004c, 2004e), some having their nearly exact counterparts in one another (compare present Fig. 2e with Fig. 33 in Ouellette et al. 1999b, and present Fig. 9d with Fig. $8 \mathrm{~b}$ in Charest et al. 2004). Hence, in light of the present and previous observations, a pathogen rather than a host origin for the elements at stake and at least some of the VWLM is proposed.

Overall, observations of the mode of tissue penetration and invasion in sumac are considered to reinforce our observations and interpretations of the other fungal wilt diseases studied by our group. These may be summarized as follows: 1) host walls may be pervaded by direct incursion of fungal cells, at times over a large area, as also by pegs and matter associated with the elements described. This might therefore indicate that host wall invasion may not necessarily be preceded by a zone of lysis due to the action of free extracellular cellulase(s); 2) numerous gold particles of the chitin probe occurring in void spaces close to fungal cells may be associated with fungal wall residues and not necessarily be due to background; 3 ) thin, band-delimited elements and membranous structures connected to them may be analogous to those associated with the VWLM; and 4) walls of fungal cells may be very thin and irregular, showing dissimilarities or lack of labelling for chitin in contact with host walls. Whether these modifications were a deterrent to the infection process in these diseases need to be examined more closely. In cases where these cells may be hindered, they may react by producing thicker walls or endocells (Charest et al. 2004) and be only temporarily delayed in their action. Here also the wall of the endocells did not label for chitin, whereas the circumscribing thin layer did. It is why all potentialities of pathogen development should be explored and evaluated in attempts to properly understand the host-parasite relationships in these diseases.

\section{ACKNOWLEDGEMENTS}

We are thankful to Mr. Sylvain Noël (formerly at Pavillon C.-E. Marchand, Université Laval) for his valuable assistance in conducting this work. The technical editing of the paper by Ms. Pamela Cheers, Ms. Isabelle Lamarre and Mr. Benoit Arsenault, Laurentian Forestry Centre (LFC), was greatly appreciated, as was the assistance of the informatics services (LFC). We are indebted to Dr. Ariane Plourde, former Research Director, and to the management of this Centre for having provided facilities for completing this work. This work was also supported in part by a NSERC research grant to the senior author and a FCAR group research grant to the last author.

\section{REFERENCES}

Armstrong, G.M., and J.K. Armstrong. 1981. Formae speciales and races of Fusarium oxysporum causing wilt diseases. Pages 391-399 in T.A. Nelson, T.A. Tousson, and R.J. Cook (eds.), Fusarium: diseases, biology, and taxonomy. Pennsylvania State University Press, University Park, PA, USA.

Beckman, C.H. 1987. The nature of wilt diseases of plants. APS Press, The American Phytopathological Society, St. Paul, MN, USA. 175 pp.

Bishop, C.D., and R.M. Cooper. 1984. Ultrastructure of vascular colonization by fungal wilt pathogens. II. Invasion of resistant cultivars. Physiol. Plant Pathol. 24 : 277-289.

Charest, P.M., G.B. Ouellette, and F.J. Pauzé. 1984. Cytological observations of early infection process by Fusarium oxysporum f.sp. radicis-lycopersici in tomato plants. Can. J. Bot. 62 : 1232-1244.

Charest, P.M., G.B. Ouellette, P. Blais, and H. Chamberland. 2004. Irregular growth forms and cell wall modifications, polygalacturonase detection, and endocell formation in Fusarium oxysporum f.sp. radicis-lycopersici infecting tomato plants, as studied ultrastructurally and cytochemically. Mycol. Prog. 3 : 137-150. 
Et-Touil, A., D. Rioux, F.M. Mathieu, and L. Bernier. 2005. External symptoms and histopathological changes following inoculation of elms putatively resistant to Dutch elm disease with genetically close strains of Ophiostoma. Can. J. Bot. 83 : 656-667.

Farr, D.F., G.F. Bills, G.P. Chamuris, and A.Y. Rossman. 1989. Fungi on plants and plant products in the United States. APS Press. The American Phytopathological Society, St. Paul, MN, USA. p. 24-25.

Fernald, M.L. 1950. Gray's manual of botany. 8th edn. American Book Company, New York, USA. 1252 pp.

Frens, G. 1973. Controlled nucleation for the regulation of the particle size in monodisperse gold solutions. Nature (Phys. Sci.) $241: 20-22$.

Hale, M.D., and R.A. Eaton. 1985a. The ultrastructure of soft rot fungi. I. Fine hyphae in wood cell walls. Mycologia $77: 447-463$

Hale, M.D., and R.A. Eaton. 1985b. The ultrastructure of soft rot fungi. II. Cavity-forming hyphae in wood cell walls. Mycologia 77 : 594-605.

Hepting, G.H., and R. Toole. 1950. Some southeastern tree diseases - 1948 and 1949. Plant Dis. Rep. 34 : 135-137.

Kirouac, C. (Fr. Marie-Victorin). 1995. Flore laurentienne. 3ième édition. L. Brouillet and I. Goulet (eds.). Mise à jour et annotée. Les Presses de I'Université de Montréal Montréal. p. 391-392.

Nicole, M., K. Ruel, and G.B. Ouellette. 1994. Fine morphology of fungal structures involved in host wall alteration. Pages 13-30 in O. Petrini and G.B. Ouellette (eds.), Host wall alterations by parasitic fungi, APS Press, The American Phytopathological Society, St. Paul, MN, USA.

O'Connell, R.J., J.A. Bailey, and D.V. Richmond. 1984. A chloroplast and other organelles of Phaseolus vulgaris within a hypha of Colletotrichum lindemuthianum. Physiol. Mol. Plant Pathol. 37 : 39-53.

Ouellette, G.B., and D. Rioux. 1992. Anatomical and physiological aspects of resistance to Dutch elm disease. Pages 257-307 in R.A. Blanchette and A.R. Biggs (eds.), Defense mechanisms of woody plants against fungi. SpringerVerlag, Berlin.

Ouellette, G.B., and D. Rioux. 1993. Alterations of vessel elements and reactions of surrounding tissues in the DED syndrome. Pages 255-292 in M.B. Sticklen and J.L. Sherald (eds.), Dutch elm disease research: cellular and molecular approaches. Springer-Verlag, New York.

Ouellette, G.B., N. Méthot, H. Chamberland, C. Côté, and J.-G. Lafontaine. 1995. Cytology of irregular growth forms of Ophiostoma ulmi and Ophiostoma novo-ulmi growing through millipore filter membranes and sterilized elm wood sections. Can. J. Microbiol. 41 : 1095-1110.

Ouellette, G.B., R.P. Baayen, M. Simard, and D. Rioux. 1999a. Ultrastructural and cytochemical study of colonization of xylem vessel elements of susceptible and resistant Dianthus caryophyllus by Fusarium oxysporum f. sp. dianthi. Can. J. Bot. 77 : 644-663.

Ouellette, G.B., H. Chamberland, A. Goulet, M. Lachapelle, and J.-G. Lafontaine. 1999b. Fine structure of the extracellular sheath and cell walls in Ophiostoma novo-ulmi growing on various substrates. Can. J. Microbiol. 45 : 582-597.

Ouellette, G.B., R.P. Baayen, L. Bernier, H. Chamberland, P.M. Charest, D. Rioux, and M. Simard. 2001. Chitin : to be or not to be in some ascomycetous fungi. Pages 79-89 in R.A.A. Muzzarelli (ed.), Chitin Enzymology 2001. Atec Edizioni, Grottamare, Italia.

Ouellette, G.B., R.P. Baayen, M. Simard, and D. Rioux. 2002. Reactions of paratracheal cells of resistant and susceptible carnation (Dianthus caryophyllus) cultivars to vascular invasion by Fusarium oxysporum f.sp. dianthi. New Phytol. 156 : 113-128.
Ouellette, G.B., R.P. Baayen, H. Chamberland, M. Simard, D. Rioux, and P.M. Charest. 2004a. Cytochemical labeling for fungal and host components in plant tissues inoculated with fungal wilt pathogens. Microsc. Microanal. 10 : 449-461.

Ouellette, G.B., R.P. Baayen, D. Rioux, and M. Simard. 2004b. Peculiar ultrastructural characteristics of fungal cells and of other elements apposed to and in vessel walls in plants of a susceptible carnation cultivar, infected with Fusarium oxysporum f.sp. dianthi race 2. Phytoprotection $85: 121-138$

Ouellette, G.B., D. Rioux, M. Simard, and R.P. Baayen. 2004c. Occurrence of paracrystalloids and their particles in resistant and susceptible carnation plants infected with Fusarium oxysporum f.sp. dianthi race 2. Phytoprotection $85: 139-151$

Ouellette, G.B., D. Rioux, M. Simard, and M. Cherif. 2004d. Ultrastructural and cytochemical studies of hosts and pathogens in some fungal wilt diseases: retro- and introspection towards a better understanding of DED. In L. Gil, A. Solla, and G.B. Ouellette (eds.), New approaches to elm conservation. Investig. Agrar.: Sist. Recur. For. 13 : 119-143.

Ouellette, G.B., D. Rioux, M. Simard, H. Chamberland, M. Cherif, and R.P. Baayen. 2004e. Ultrastructure of the alveolar network and its relation to coating on vessel walls in elms infected with Ophiostoma novo-ulmi and in other plants affected with similar wilt diseases. In L. Gil, A. Solla, and G.B. Ouellette (eds.), New approaches to elm conservation. Investig. Agrar.: Sist. Recur. For. 13 : 147-160.

Ouellette, G.B., D. Rioux, and M. Simard. 2005. Histopathology of Fusarium wilt of staghorn sumac (Rhus typhina) caused by Fusarium oxysporum f. sp. callistephi race 3. II. Characteristics of opaque matter associated with extensive host cell and cell wall alterations. Phytoprotection 86 : 175-187.

Rioux, D., and G.B. Ouellette. 1991. Barrier zone formation in host and nonhost trees inoculated with Ophiostoma novo-ulmi. I. Anatomy and histochemistry. Can. J. Bot. 69 : 2055-2073.

Rioux, D., M. Nicole, M. Simard, and G.B. Ouellette. 1998. Immunocytochemical evidence that secretion of pectin occurs during gel (gum) and tylosis formation in trees. Phytopathology 88 : 494-505.

Snyder, W.C., R.E. Toole, and G.H. Hepting. 1949. Fusaria associated with mimosa wilt, sumac wilt, and pine pitch canker. J. Agric. Res. 78 : 365-380.

Tamaki, H., and S. Yamashina. 1994. Improved method for post-embedding cytochemistry using reduced osmium and LR white resin. J. Histochem. Cytochem. 42 : 12851293.

Thomas, W.D. Jr. 1950. New shade tree diseases in Colorado. Plant Dis. Rep. 34 : 83-84.

Toole, R.E. 1949. Fusarium wilt of staghorn sumac. Phytopathology $39: 754-759$.

Toole, R.E., W.C. Snyder, and G.H. Hepting. 1948. A new Fusarium wilt of sumac. Phytopathology $38: 572$ (abstr.). 